\title{
Characterisation of Neuropeptide Y Receptor Subtypes by Synthetic NPY Analogues and by Anti-receptor Antibodies
}

\section{Christophe P. Eckard ${ }^{1}$, Chiara Cabrele ${ }^{1}$, Heike A. Wieland ${ }^{2}$ and Annette G. Beck-Sickinger ${ }^{1,3, *}$}

${ }^{1}$ Department of Applied Bioscience, Federal Institute of Technology (ETH) Zürich, Winterthurer Str. 190, 8057 Zürich, Switzerland

${ }^{2}$ Division of Preclinical Research, Boehringer Ingelheim Pharma AG, 88397 Biberach, Germany

${ }^{3}$ Institute of Biochemistry, University of Leipzig, Talstr. 33, 04103 Leipzig, Germany. Tel + 4934197 36 900; FAX: + 493419736998

* To whom correspondence should be addressed; E-Mail: beck-sickinger@ uni-leipzig.de

${ }^{\ddagger}$ Presented at the $4^{\text {th }}$ Electronic Conference on Synthetic Organic Chemistry, September 1-30, 2000, (Paper C0036).

Received: 1 November 2000 / Accepted: 6 November 2000 / Published: 30 April 2001

\begin{abstract}
Neuropeptide Y (NPY), a 36-mer neuromodulator, binds to the receptors $\mathrm{Y}_{1}, \mathrm{Y}_{2}$, $\mathrm{Y}_{4}$ and $\mathrm{Y}_{5}$ with nanomolar affinity. They all belong to the rhodopsin-like G-protein coupled, seven transmembrane helix spanning receptors. In this study, Ala-substituted and centrally truncated NPY analogues were compared with respect to affinity to the Yreceptors. Furthermore, antibodies against the second (E2) and the third (E3) extracellular loop of NPY $\mathrm{Y}_{1^{-}}, \mathrm{Y}_{2^{-}}$and $\mathrm{Y}_{5}$-receptor subtypes were raised and affinity to intact cells was tested by immunofluorescence assays. Both methods were applied in order to receive subtype selective tools and to characterise ligand binding. The analogues $\left[\mathrm{A}^{13}\right]$-pNPY and $\left[\mathrm{A}^{27}\right]$-pNPY showed subtype selectivity for the $\mathrm{Y}_{2}$-receptor. Sera against the E2 loop of the $\mathrm{Y}_{1}$-receptor and against the $\mathrm{E} 2$ loop of the $\mathrm{Y}_{2}$-receptor were subtype selective. Two antibodies against the $\mathrm{Y}_{5} \mathrm{E} 2$ and $\mathrm{E} 3$ loop recognised the $\mathrm{Y}_{5^{-}}$and $\mathrm{Y}_{2}$-receptor subtypes. In combination, these sera are able to distinguish between the $\mathrm{Y}_{1^{-}}, \mathrm{Y}_{2^{-}}$, and $\mathrm{Y}_{5}$-receptor subtypes. The analogues and antibodies represent valuable tools to distinguish NPY receptors on membranes and intact cells.
\end{abstract}


Keywords: neuropeptide Y; NPY analogues; anti-receptor antibodies; NPY receptor; subtype selectivity; ligand-binding site.

\begin{abstract}
Abbreviations: BHK, baby hamster kidney; Boc, tert-butyloxycarbonyl; BSA, bovine serum albumin; CT, C-terminal segment; DMEM, Dulbecco's modified Eagle's medium; DMF, dimethyl-formamide; E1-3, extracellular loops 1-3; EDTA, ethylenediaminetetraacetic acid; ELISA, enzyme linked immunosorbent assay; FCA, Freund's complete adjuvant; FCS, fetal calf serum; Fmoc, fluorenyl-9-methoxycarbonyl; FITC, 4(5)fluoresceinisothiocyanate; HPLC, high performance liquid chromatography; hPP, human pancreatic polypeptide; Ig, immune globulin; KLH, keyhole limpet hemocyanin; MEM, minimum essential medium; NPY, neuropeptide Y; NT, N-terminal segment; PBS, phosphate buffered saline; pNPY, porcine neuropeptide Y; Pmc, pentamethylchromanesufonyl; TBS, Tris buffered saline; tBu, tert-butyl; (Tmd)Phe, 4'-(3-trifluoromethyl)-3diazirine-3-yl-phenylalanine; Trt, trityl; TFA, trifluoroacetic acid
\end{abstract}

\title{
Introduction
}

Neuropeptide Y (NPY) is a 36 amino acid peptide hormone that belongs to the pancreatic polypeptide hormone family [1]. It is widely distributed both peripherally and centrally. Similar to many other neurotransmitters, NPY elicits diverse physiological effects. One of the most striking actions of NPY is the stimulation of food intake in a variety of vertebrate species [2]. But also various other biological effects have been attributed to NPY, e.g., profound effects on secretion of luteinising hormone as well as on growth hormone and insulin release [3-5]. These observations suggest the important role of NPY in the pathophysiology of obesity and diabetes. Furthermore, it has been reported that NPY elicits potent vasoconstriction [6], facilitates learning and memory retention processes [7], modulates locomotor behaviours [8], produces hypothermia [9, 10], inhibits sexual behaviour [11], shifts the circadian rhythms [12], modulates cardiorespiratory parameters [13], generates anxiolytic effects [14], and inhibits alcohol consumption and resistance [15]. Accordingly, NPY is a neuronal and endocrine messenger that exerts its effects via several receptor subtypes. Five distinct NPY receptor subtypes have been cloned and pharmacologically characterised [16]. They are named $\mathrm{Y}_{1^{-}}$[17-19], $\mathrm{Y}_{2^{-}}$[20-22], $\mathrm{Y}_{4} / \mathrm{PP}_{1^{-}}[23,24], \mathrm{Y}_{5^{-}}$[25] and $\mathrm{y}_{6^{-}}$[26] receptor subtypes. All subtypes belong to the large superfamily of the G-protein-coupled, heptahelical receptors [27]. The different receptor subtypes are localised in various tissues, in the central nervous system as well as in the periphery. Tissues with high density of NPY receptors are blood vessels, kidney, adrenal glands, colon, heart, pancreas, intestine, nerve endings and brain [2]. The broad physiological relevance of NPY gives reason for an increasing interest in NPY as a new target in drug discovery. 
It is not yet fully understood which NPY receptor subtype is related to a certain physiological effect. Available evidence suggests for example that the $Y_{1^{-}}$or $Y_{5}$-receptor or even both receptors together regulate the food intake behaviour [2]. Furthermore, the receptor subtypes are distributed heterogeneously in various tissues. Therefore, receptor subtype selective tools are very important for understanding the biological role and distribution of the receptors and can provide important knowledge for drug design.

Each receptor subtype recognises specific parts of the hormone folded in an unique conformation. Thus, different receptor subtypes can be characterised by selectively increasing the affinity/activity of peptide analogues in cells or tissue [28]. Generally, full length analogues are obtained by D-amino acid- or L-alanine-scan or by further amino acid replacements [29]. Frequently, the native ligands are shortened by deletion of the C- or N-terminal parts, or by central truncation [30]. Moreover, analogues with agonistic or antagonistic activity can be a powerful tool to investigate the biological function of a receptor subtype.

Antibodies produced against hormone receptors are valuable tools for investigating the receptor localisation on cells or tissue, regulation and desensitisation [31-37]. Anti-receptor antisera can be raised by immunisation with purified, enriched receptors [33] or by immunisation with receptor fragments [32-35]. Antibodies specifically recognising the NPY receptor subtypes can be used to determine either the localisation pattern and the quality of the receptor protein expression or the topology and function of a receptor subtype [38].

In this study we describe synthetic NPY analogues tested in binding assays against the Y-receptors and we compare the binding of antibodies raised against the second and the third extracellular loop of NPY $\mathrm{Y}_{1^{-}}, \mathrm{Y}_{2^{-}}$and $\mathrm{Y}_{5}$-receptor subtypes to intact cells in immunofluorescence assays. Both methods are applied in order to get subtype selectivity and to obtain tools to localise the different receptor subtypes (Table 1).

\section{Results and Discussion}

\section{Synthesis of the Analogues and Receptor Segments}

All peptides were designed as amino acid mono-substituted full length or centrally truncated analogues of pNPY and hPP and were obtained by multiple automatic solid phase peptide synthesis using the Fmoc strategy.

The size of the receptor segment peptides ranged between 19 and 20 amino acids, in order to increase the probability that the peptides fold into an ordered structure. The peptides were characterised by analytical HPLC and electrospray ionization mass spectrometry. 


\section{Table 1}

Sequence and analytical data of the peptides used to generate anti-receptor antibodies. The peptides are named according to the receptor and the loop from which they were derived.

\begin{tabular}{|l|l|l|l|l|}
\hline \multicolumn{1}{|c|}{ Name } & \multicolumn{1}{|c|}{ Sequence } & $\begin{array}{c}\text { Mass }_{\text {calc }} \\
{[\mathrm{Da}]}\end{array}$ & $\begin{array}{c}\text { Mass }_{\mathrm{ex}} \\
\mathrm{p} \\
{[\mathrm{Da}]}\end{array}$ & $\begin{array}{c}\text { Position in the } \\
\text { receptor }\end{array}$ \\
\hline $\mathrm{Y}_{1}$ E2/2 & Q I L T D E P F Q N V S L A A F K D K & 2163.5 & 2165 & $76-94$ (rat) \\
\hline$Y_{2}$ E2/1 & IF R E Y S L I E I I P D F I V A F & 2313.7 & 2314 & $75-93^{\text {a }}$ (human) \\
\hline$Y_{5}$ E2/2 & L L S S R Y L C V E S W P S D S Y R I A F & 2491.9 & 2491 & $186-206$ (human) \\
\hline$Y_{5}$ E3 & H V V T D F N D N L I S N R H F K L V & 2267.6 & 2268 & $278-296$ (human) \\
\hline
\end{tabular}

${ }^{a}$ At the position 93 the natural amino acid Cys was substituted by Phe.

\section{Characterisation of the Sera}

The total absorption $(405 \mathrm{~nm})$ of the antibodies tested against the peptides ranged from 0.15 to 0.45. The values of preimmune sera ranged from 0.10 to 0.36 . They were subtracted from the total absorption to obtain specific binding. The blank values were under 0.05. All antisera showed specific binding.

\section{Binding Potency of Full Length NPY Analogues}

The affinity to the receptors $Y_{1}$ and $Y_{2}$ of all 36 Ala-substituted analogues of NPY has been reported previously [40]. In the present work, we have considered sixteen selected Ala-substituted NPY analogues and investigated their binding affinity additionally at the human receptors $Y_{4}$ and $Y_{5}$. $\mathrm{Y}_{1^{-}}$and $\mathrm{Y}_{2}$-receptor binding data are listed for comparison (Table 2). The substitution of Pro at the positions 2, 5, 8 and 13 led in general to a decreased affinity. In particular, the substitution of the residues 2 and 5 reduced the $\mathrm{hY}_{1}$-receptor affinity about 500- and 1000-fold, respectively; the substitution of Pro 5 decreased the $h \mathrm{Y}_{2}$-receptor affinity 600-fold, and the replacement of Pro 8 led to a 11- and 69-fold lower affinity at the $\mathrm{hY}_{4}$ - and $\mathrm{hY}_{5}$-receptor subtypes, respectively. By single exchange of any of the aromatic side chains of the Tyr residues, the positions 27 and 36 resulted to be the most important for the binding at the $\mathrm{hY}_{1}$-receptor, with a loss of affinity of 1000- and 4200-fold after substitution, respectively, whereas the presence of $\mathrm{Ala}^{20}$ was characterised by a 300 -fold reduced affinity at this receptor. The binding at the $h \mathrm{Y}_{2}$-receptor was drastically decreased (1200-fold) only by 
the substitution of $\mathrm{Tyr}^{36}$. The $\mathrm{hY}_{4}$-receptor binding showed to be only slightly influenced by the Tyr/Ala replacement (up to 62-fold lower affinity), while the binding at the hY 5 -receptor was reduced

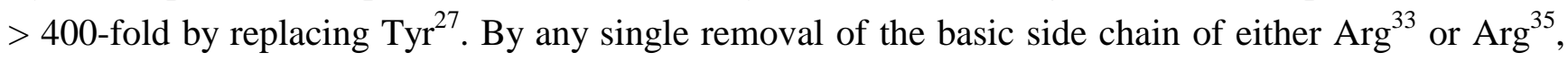
we observed a complete loss of affinity for the $\mathrm{hY}_{1}$-receptor (> 4000-fold); by exchange of $\mathrm{Arg}^{19}$ and $\mathrm{Arg}^{25}$ the binding was 1200- and 48-fold less potent, respectively. The hY $\mathrm{Y}_{2}$-receptor binding was totally lost by substitution of $\mathrm{Arg}^{35}$ and was reduced > 1300-fold by $\mathrm{Arg}^{33}$ exchange. These two C-terminal Arg residues proved to be very important also for the binding at the $\mathrm{hY}_{4}$ - and $\mathrm{h} \mathrm{Y}_{5}$-receptor subtypes, especially $\mathrm{Arg}^{35}$ is required for affinity to the $\mathrm{hY}_{5}$-receptor (> 1200-fold lower affinity after replacement with Ala). Interestingly, the $\left[\mathrm{Ala}^{19}\right]$-pNPY analogue was almost as potent as the native ligand at the $\mathrm{hY}_{5}$-receptor and even slightly better at the $\mathrm{hY}_{4}$-receptor. By removing the negative charge of $\mathrm{Asp}^{11}$, we could obtain a slightly more potent ligand at the receptors $\mathrm{hY}_{4}$ and $\mathrm{hY}$, whereas

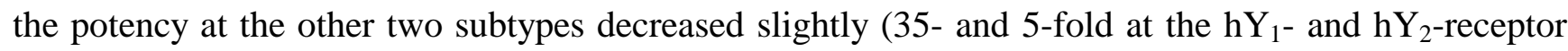
subtypes, respectively). The decrease in hydrophilicity at the position 32 by substitution of Thr with

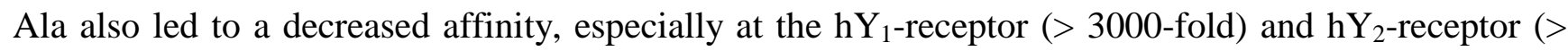
1000-fold). These two receptors were also the most sensitive to the substitution of $\mathrm{Gln}^{34}$, while the binding at the receptors $\mathrm{hY}_{4}$ and $\mathrm{hY} \mathrm{Y}_{5}$ remained almost as good as for the native ligand. Moreover, the analogue $\left[\mathrm{Leu}^{34}\right]$-pNPY could bind the $\mathrm{hY}_{4}$-receptor 18-fold more potently than pNPY itself. Instead, the presence of D-Pro ${ }^{34}$ considerably reduced the affinity at all receptor subtypes, whereas it was previously reported that L-Pro at the same position was perfectly tolerated at the receptors $\mathrm{hY}_{1}, \mathrm{hY}_{4}$ and $\mathrm{hY}_{5}$, but not at the $\mathrm{hY}_{2}$-receptor [25]. $\mathrm{IC}_{50}$ values of the full length NPY analogues are summarised in Table 2.

\section{TABLE 2}

Analytical (top) and biological (bottom) data of amino acid mono-substituted and centrally truncated NPY analogues. In brackets the affinity of the peptide divided by the affinity of pNPY is given.

\begin{tabular}{|c|c|c|}
\hline Peptide & $\begin{array}{c}\text { Mass }_{\text {calc. }} \\
{[\mathrm{Da}]}\end{array}$ & $\begin{array}{c}\text { Mass }_{\text {exp }} \\
{[\mathrm{Da}]}\end{array}$ \\
\hline pNPY & 4253.7 & 4253 \\
\hline$\left[\mathrm{A}^{1}\right]-\mathrm{pNPY}$ & 4161.7 & 4162 \\
\hline$\left[\mathrm{A}^{2}\right]-\mathrm{pNPY}$ & 4227.7 & 4224 \\
\hline$\left[\mathrm{A}^{5}\right]-\mathrm{pNPY}$ & 4227.7 & 4228 \\
\hline$\left[\mathrm{A}^{8}\right]-\mathrm{pNPY}$ & 4227.7 & 4225 \\
\hline$\left[\mathrm{A}^{11}\right]-\mathrm{pNPY}$ & 4209.7 & 4210 \\
\hline$\left[\mathrm{A}^{13}\right]-\mathrm{pNPY}$ & 4227.7 & 4226 \\
\hline
\end{tabular}




\begin{tabular}{|c|c|c|}
\hline$\left[\mathrm{A}^{19}\right]-\mathrm{pNPY}$ & 4168.6 & 4169 \\
\hline$\left[\mathrm{A}^{20}\right]-\mathrm{pNPY}$ & 4161.7 & 4160 \\
\hline$\left[\mathrm{A}^{21}\right]-\mathrm{pNPY}$ & 4161.7 & 4160 \\
\hline$\left[\mathrm{A}^{25}\right]-\mathrm{pNPY}$ & 4168.7 & 4167 \\
\hline$\left[\mathrm{A}^{27}\right]-\mathrm{pNPY}$ & 4161.7 & 4159 \\
\hline$\left[\mathrm{A}^{32}\right]-\mathrm{pNPY}$ & 4223.8 & 4221 \\
\hline$\left[\mathrm{A}^{33}\right]-\mathrm{pNPY}$ & 4168.7 & 4167 \\
\hline$\left[\mathrm{A}^{34}\right]-\mathrm{pNPY}$ & 4196.7 & 4195 \\
\hline$\left[\mathrm{A}^{35}\right]-\mathrm{pNPY}$ & 4168.7 & 4167 \\
\hline$\left[\mathrm{A}^{36}\right]-\mathrm{pNPY}$ & 4161.7 & 4158 \\
\hline$\left[\mathrm{L}^{34}\right]-\mathrm{pNPY}$ & 4238.8 & 4238 \\
\hline$\left[\mathrm{D}-\mathrm{P}^{34}\right]-\mathrm{pNPY}$ & 4222.8 & 4222 \\
\hline$\left[\mathrm{Ahx}^{5-24}\right]-\mathrm{NPY}$ & 2220.6 & 2219 \\
\hline$\left[\mathrm{Ahx}{ }^{5-24,} \mathrm{P}^{34}\right]-\mathrm{NPY}$ & 2189.6 & 2190 \\
\hline$\left[\mathrm{Ahx}{ }^{8-20}\right]-\mathrm{NPY}$ & 2981.4 & 2980 \\
\hline$\left[\mathrm{Ahx}^{8-19}\right]-\mathrm{NPY}$ & 3144.6 & 3144 \\
\hline$\left[\mathrm{Ahx}{ }^{9-20}\right]-\mathrm{NPY}$ & 3078.6 & 3078 \\
\hline$\left[\mathrm{Ahx}{ }^{9-17}\right]-\mathrm{NPY}$ & 3469.0 & 3470 \\
\hline $\mathrm{hPP}$ & 4181.8 & 4181 \\
\hline$\left[\mathrm{Ahx}^{5-24}\right]-\mathrm{hPP}$ & 2161.6 & 2162 \\
\hline$\left[\mathrm{Ahx}^{5-20}\right]-\mathrm{hPP}$ & 2532.0 & 2531 \\
\hline$\left[\mathrm{Y}^{5-20}\right]-\mathrm{hPP}$ & 2582.0 & 2582 \\
\hline
\end{tabular}

\begin{tabular}{|c|c|c|c|c|c|c|c|c|}
\hline \multirow[b]{2}{*}{ Peptide } & \multicolumn{8}{|c|}{$\mathrm{IC}_{50}$} \\
\hline & $\begin{array}{c}\mathrm{hY}_{1} \\
{[\mathrm{nM}]}\end{array}$ & $\frac{\mathrm{IC}_{50}(\mathrm{Pep})}{\mathrm{IC}_{50}(\mathrm{NPY})}$ & $\begin{array}{c}\mathrm{hY}_{2} \\
{[\mathrm{nM}]}\end{array}$ & $\frac{\mathrm{IC}_{50}(\mathrm{Pep})}{\mathrm{IC}_{50}(\mathrm{NPY})}$ & $\begin{array}{c}\mathrm{hY}_{4} \\
{[\mathrm{nM}]}\end{array}$ & $\frac{\mathrm{IC}_{50}(\mathrm{Pep}) \mathrm{IC}_{50}}{(\mathrm{NPY})}$ & $\begin{array}{c}\mathrm{hY}_{5} \\
{[\mathrm{nM}]}\end{array}$ & $\frac{\mathrm{IC}_{50}(\mathrm{Pep})}{\mathrm{IC}_{50}(\mathrm{NPY})}$ \\
\hline pNPY & 0.23 & (1) & 0.04 & (1) & 5.5 & (1) & 0.8 & (1) \\
\hline$\left[\mathrm{A}^{1}\right]-\mathrm{pNPY}$ & 21 & $(91)$ & 0.2 & $(5)$ & 5.8 & $(1.1)$ & 2.2 & $(2.8)$ \\
\hline$\left[\mathrm{A}^{2}\right]-\mathrm{pNPY}$ & 114 & $(496)$ & 0.3 & (8) & 7.8 & (1.4) & 5.5 & (7) \\
\hline$\left[\mathrm{A}^{5}\right]-\mathrm{pNPY}$ & 228 & $(991)$ & 24 & $(600)$ & 25 & $(4.5)$ & 32 & $(40)$ \\
\hline$\left[\mathrm{A}^{8}\right]-\mathrm{pNPY}$ & 32 & (139) & 0.7 & (18) & 60 & $(11)$ & 55 & $(69)$ \\
\hline$\left[\mathrm{A}^{11}\right]-\mathrm{pNPY}$ & 8.0 & (35) & 0.2 & (5) & 3.1 & $(0.6)$ & 0.5 & $(0.6)$ \\
\hline$\left[\mathrm{A}^{13}\right]-\mathrm{pNPY}$ & 7.5 & $(33)$ & 0.1 & (3) & 37 & $(6.7)$ & 17 & (21) \\
\hline$\left[\mathrm{A}^{19}\right]-\mathrm{pNPY}$ & 282 & $(1226)$ & 1.6 & $(40)$ & 4.1 & $(0.7)$ & 1.4 & $(1.8)$ \\
\hline$\left[\mathrm{A}^{20}\right]-\mathrm{pNPY}$ & 71 & (309) & 1.2 & $(30)$ & 161 & (29) & 19 & $(24)$ \\
\hline$\left[\mathrm{A}^{21}\right]-\mathrm{pNPY}$ & 5.5 & (24) & 0.2 & $(5)$ & 66 & (12) & 32 & (40) \\
\hline$\left[\mathrm{A}^{25}\right]-\mathrm{pNPY}$ & 11 & (48) & 0.7 & $(18)$ & 201 & $(37)$ & 80 & $(100)$ \\
\hline$\left[\mathrm{A}^{27}\right]-\mathrm{pNPY}$ & 250 & (1087) & 1.4 & (35) & 340 & $(62)$ & 370 & (463) \\
\hline
\end{tabular}




\begin{tabular}{|c|c|c|c|c|c|c|c|c|}
\hline$\left[\mathrm{A}^{32}\right]-\mathrm{pNPY}$ & 723 & $(3143)$ & 45 & $(1125)$ & 380 & $(69)$ & 7.7 & $(9.5)$ \\
\hline$\left[\mathrm{A}^{33}\right]-\mathrm{pNPY}$ & $>1000$ & $(>4348)$ & 54 & $(1350)$ & $>1000$ & $(>182)$ & 94 & $(118)$ \\
\hline$\left[\mathrm{A}^{34}\right]-\mathrm{pNPY}$ & 94 & $(409)$ & 6.0 & $(150)$ & 7.4 & $(1.3)$ & 1.3 & $(1.6)$ \\
\hline$\left[\mathrm{A}^{35}\right]-\mathrm{pNPY}$ & $>1000$ & $(>4348)$ & $>1000$ & $(>25000)$ & $>1000$ & $(>182)$ & $>1000$ & $(>1250)$ \\
\hline$\left[\mathrm{A}^{36}\right]-\mathrm{pNPY}$ & 970 & $(4217)$ & 48 & $(1200)$ & 141 & $(26)$ & 68 & $(85)$ \\
\hline$\left[\mathrm{L}^{34}\right]-\mathrm{pNPY}$ & & & & & 0.3 & $(0.05)$ & 1.8 & $(2.3)$ \\
\hline$\left[\mathrm{D}-\mathrm{P}^{34}\right]-\mathrm{pNPY}$ & 266 & $(1157)$ & & & 271 & $(49)$ & 156 & (195) \\
\hline$\left[\mathrm{Ahx}^{5-24}\right]-\mathrm{NPY}$ & $>1000$ & $(>4348)$ & 1.4 & $(35)$ & 600 & $(109)$ & 795 & (994) \\
\hline $\begin{array}{c}{\left[\mathrm{Ahx}^{5-24,} \mathrm{P}^{34}\right]-} \\
\mathrm{NPY}\end{array}$ & $>1000$ & $(>4348)$ & & & 514 & $(93)$ & $>10000$ & $(>12500)$ \\
\hline$\left[\mathrm{Ahx}^{8-20}\right]-\mathrm{NPY}$ & 28 & $(122)$ & & & 67 & $(12)$ & 31 & (39) \\
\hline$\left[\mathrm{Ahx}^{8-19}\right]-\mathrm{NPY}$ & 46 & $(200)$ & & & 95 & (17) & 19 & (24) \\
\hline$\left[\mathrm{Ahx}^{9-20}\right]-\mathrm{NPY}$ & 74 & (322) & & & 108 & $(20)$ & 29 & $(36)$ \\
\hline$\left[\mathrm{Ahx}^{9-17}\right]-\mathrm{NPY}$ & 13 & $(57)$ & & & 45 & (8) & 11 & (14) \\
\hline $\mathrm{hPP}$ & $>1000$ & $(>4348)$ & $>1000$ & $(>25000)$ & 0.04 & $(0.007)$ & 24 & $(30)$ \\
\hline$\left[\mathrm{Ahx}^{5-24}\right]-\mathrm{hPP}$ & $>500$ & $(>2174)$ & $>1000$ & $(>25000)$ & 144 & (26) & $>1000$ & $(>1250)$ \\
\hline$\left[\mathrm{Ahx} \mathrm{x}^{5-20}\right]-\mathrm{hPP}$ & $>1500$ & $(>6522)$ & $>1000$ & $(>25000)$ & 216 & (39) & $>7000$ & $(>8750)$ \\
\hline$\left[\mathrm{Y}^{5-20}\right]-\mathrm{hPP}$ & $>500$ & $(>2174)$ & $>1000$ & $(>25000)$ & 27 & $(5)$ & $>5000$ & $(>6250)$ \\
\hline
\end{tabular}

\section{Binding Potency of Centrally Truncated NPY Analogues}

The central segment of pNPY was suggested to be important for the peptide conformation and to adopt a turn-like structure that induces the molecule to fold like a hairpin [41]. This was investigated by the preparation of pNPY analogues, where the central region was removed and substituded by a spacer like 6-amino hexanoic acid (Ahx) [42]. By varying the cutting position either at the $\mathrm{N}$ - or the $\mathrm{C}$ terminus, it was found that the analogue $\left[\mathrm{Ahx}^{5-24}\right]$-pNPY could selectively bind to the $\mathrm{hY}_{2}$-receptor with $1.4 \mathrm{nM}$ affinity (Table 2). Furthermore, analogues with longer $\mathrm{N}$ - and C-terminal fragments showed similar affinity at the $\mathrm{hY}_{1}$-receptor but also significant affinity at the receptors $\mathrm{hY}_{4}$ and $\mathrm{hY} \mathrm{Y}_{5}$.

Among these analogues, the one with the highest number of residues at the $\mathrm{N}$ - and $\mathrm{C}$-termina, $\left[\mathrm{Ahx}^{9-17}\right]$-pNPY, was the most potent ligand $\left(13 \mathrm{nM}\right.$ at the $\mathrm{hY}_{1}, 45 \mathrm{nM}$ at the $\mathrm{hY}_{4}$ and $11 \mathrm{nM}$ at the $\mathrm{hY}_{5}$ ). Accordingly, the residues 9 to 18 are not of major importance for receptor affinity.

Three centrally truncated analogues of hPP were also investigated for binding to the Y-receptors. The ligands containing the Ahx moiety instead of the middle segments 5-24 and 5-20 did not show any affinity at the $\mathrm{hY}_{1}$ - and $\mathrm{hY}_{5}$-receptor subtypes, and their affinity to the $\mathrm{hY}_{4}$-receptor was considerably reduced. Interestingly, the analogue $\left[\mathrm{Tyr}^{5-20}\right]-\mathrm{hPP}$ was found to selectively bind the $\mathrm{hY}_{4}$-receptor, however with a 670 -fold reduced affinity. IC $_{50}$ values of the centrally truncated NPY analogues are summarised in Table 2. 
Immunofluorescence on Cells expressing Y-Receptor Subtypes

Immunofluorescence experiments were performed in order to determine the selectivity of the antibodies for the Y-receptors on receptor expressing SK-N-MC cells (neuroblastoma, hY I $_{1}$, SMSKAN cells (neuroblastoma, $\mathrm{hY}_{2}$ ) and BHK cells (baby hamster kidney cells, $\mathrm{rY}_{5}$ ). For positive control, cells were directly incubated with goat anti-rabbit FITC coupled IgG. Negative control was made with preimmune sera and by preincubation of the anti-receptor antisera with the corresponding antigen peptide to block specific binding (Figure $1 \mathrm{~B}$ ).

\section{Figure 1}

Binding of the antibody Y 1 E2/2 to: A) SK-N-MC cells (Y 1); B) SMS-KAN cells (Y 2); C) BHK cells (Y 5). Binding of the antibody Y 2 E2/1 to: D) SK-N-MC cells (Y 1); E) SMS-KAN cells (Y 2); F) BHK cells (Y 5).

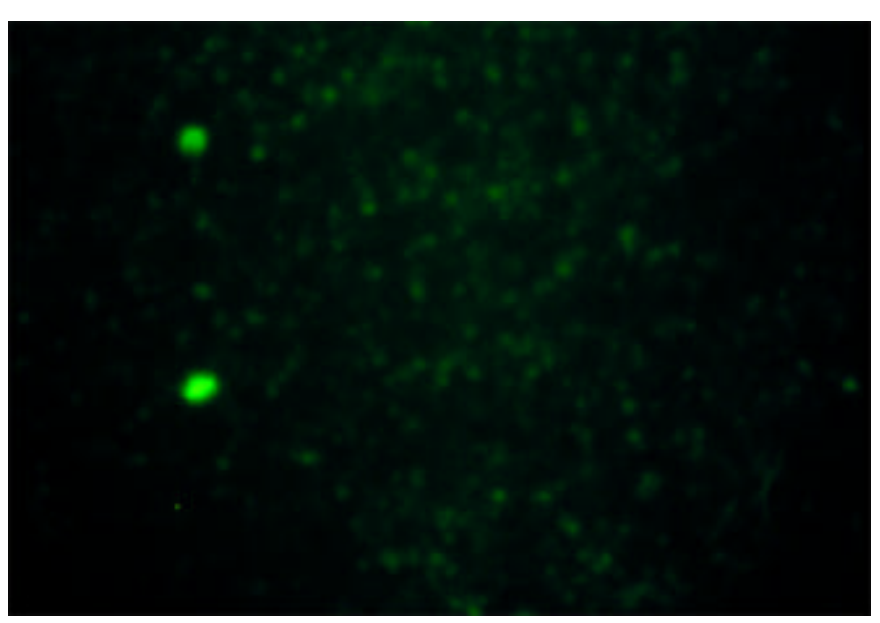

A

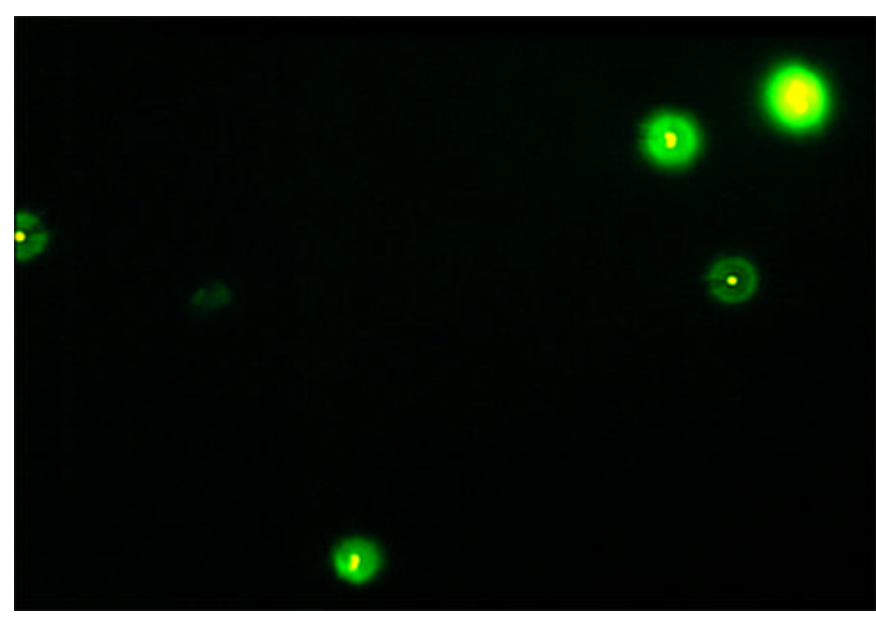

C

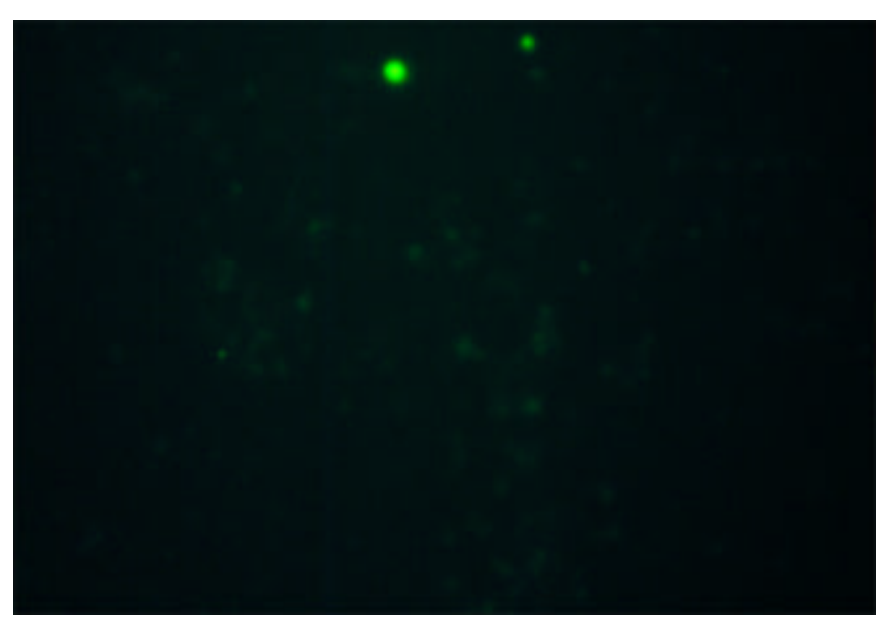

B

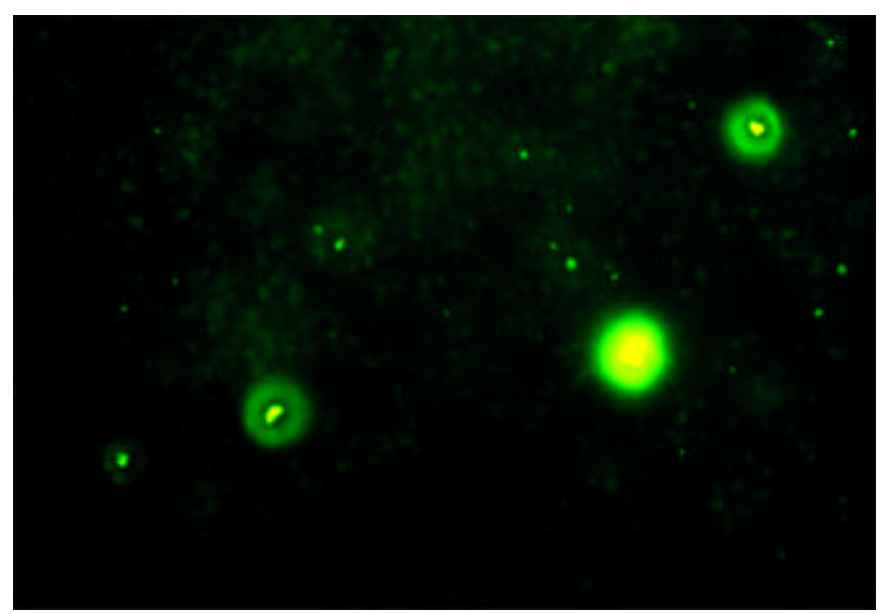

D 


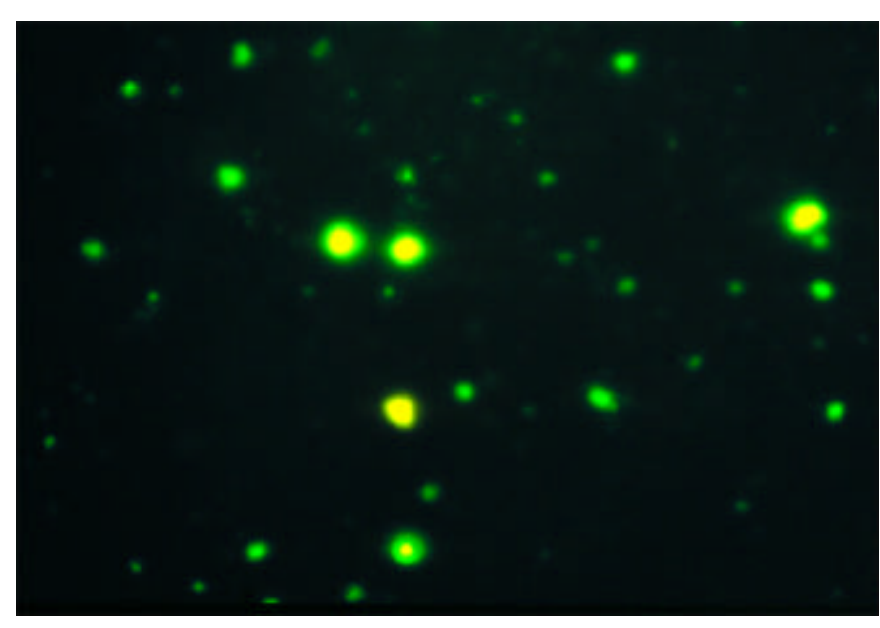

E

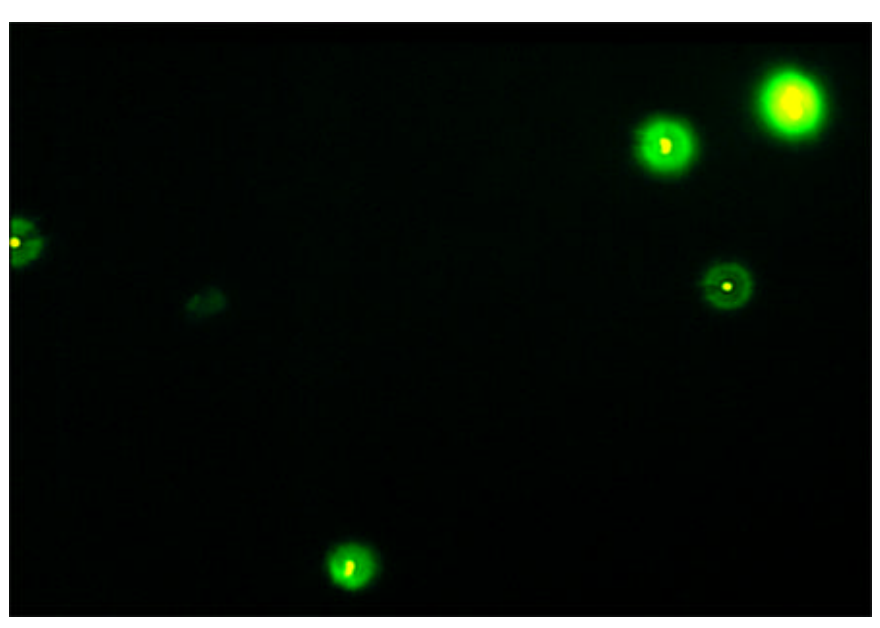

F

Antibody $\mathrm{Y}_{1} \mathrm{E} 2 / 2$ showed selective binding in the fluorescence microscope for the $\mathrm{Y}_{1}$-receptor (Figure 2 A-C). Selective binding to the $\mathrm{Y}_{2}$-receptor was detected for antibody $\mathrm{Y}_{2}$ E2/1 (Figure $2 \mathrm{D}-\mathrm{F}$ ). Very strong binding was found for the antibodies $Y_{5} E 2 / 2$ and $Y_{5} E 3$ to the receptors $Y_{2}$ and $Y_{5}$ (Figure 3 A-F). Results of the fluorescence microscope assay are summarised in Table 3.

\section{Figure 2}

Binding of the antibody $\mathrm{Y}_{5}$ E2/2 to: A) SK-N-MC cells ( $\left.\mathrm{Y}_{1}\right)$, B) SMS-KAN cells $\left.\left(\mathrm{Y}_{2}\right), \mathrm{C}\right)$ BHK cells $\left(\mathrm{Y}_{5}\right)$. Binding of the antibody $\mathrm{Y}_{5}$ E3/1 to: D) SK-N-MC cells $\left(\mathrm{Y}_{1}\right)$, E) SMSKAN cells $\left.\left(\mathrm{Y}_{2}\right), \mathrm{F}\right)$ BHK cells $\left(\mathrm{Y}_{5}\right)$.

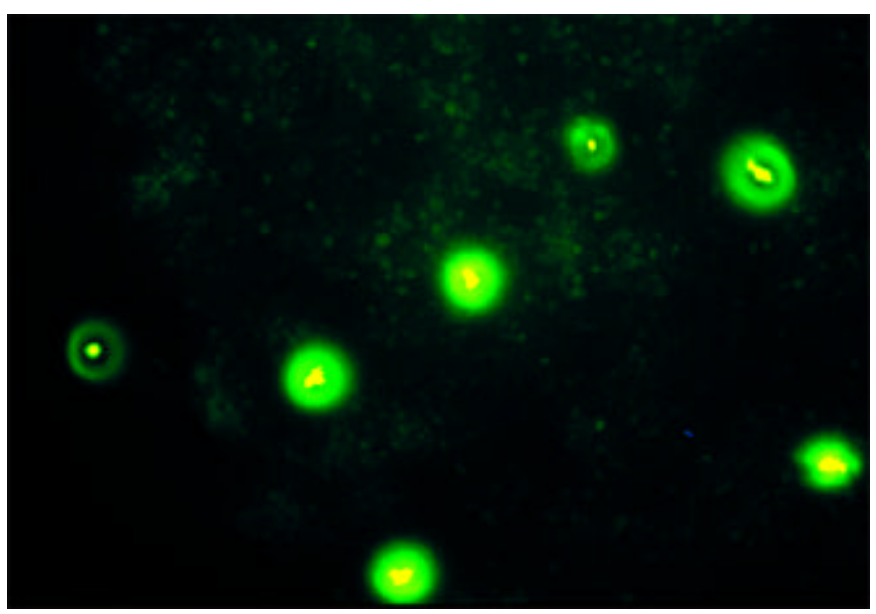

A

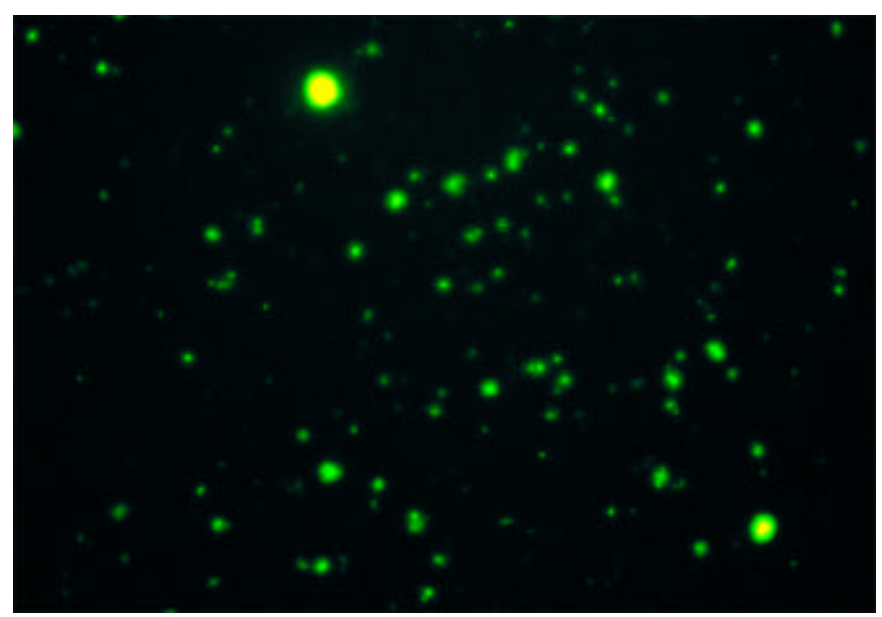

B 


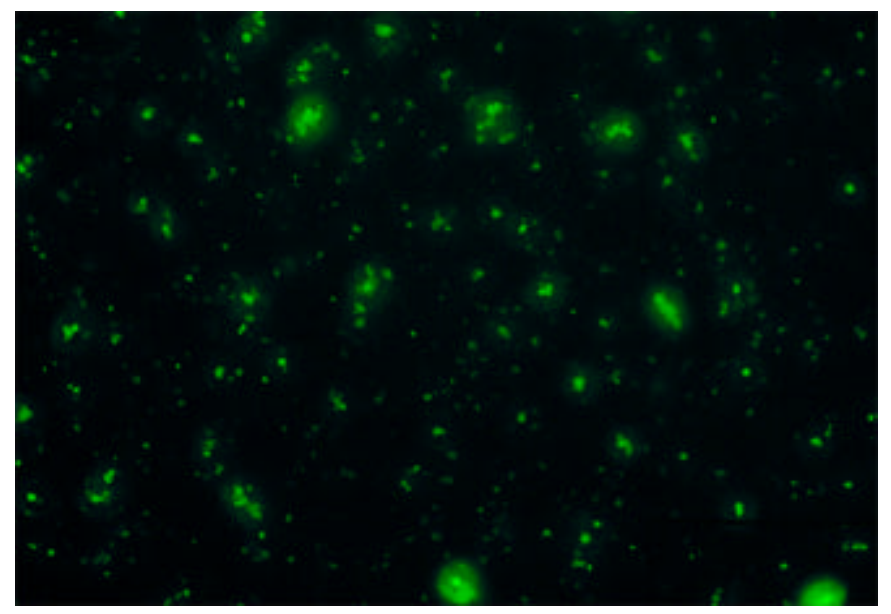

C

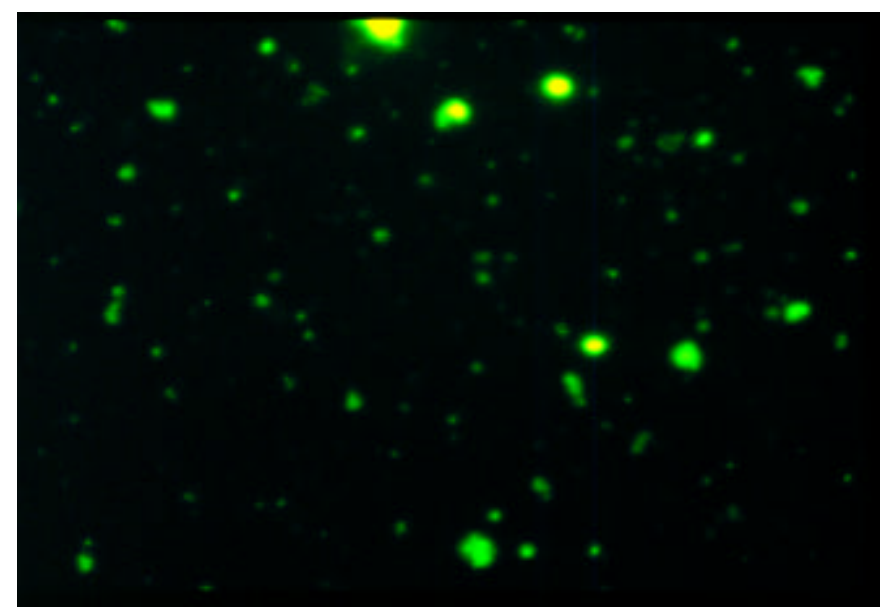

$\mathbf{E}$

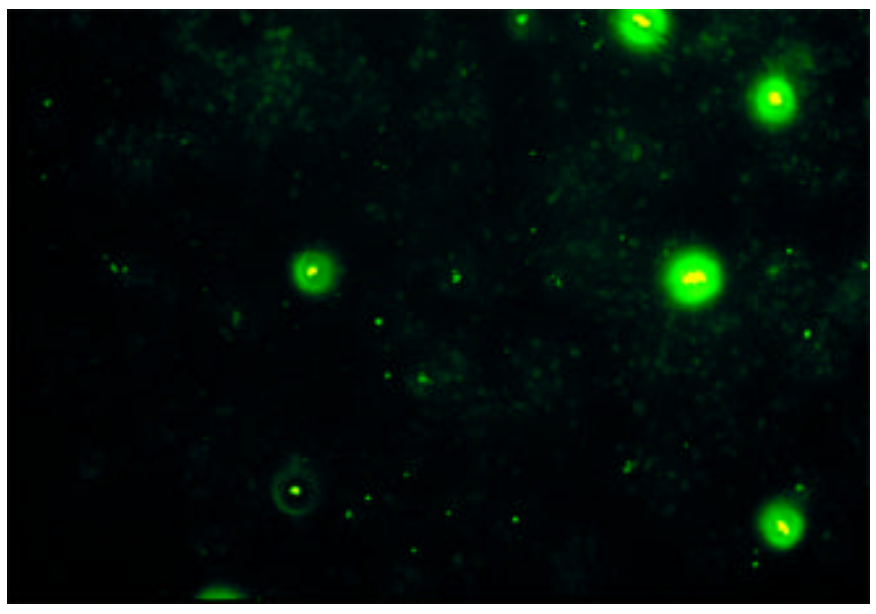

D

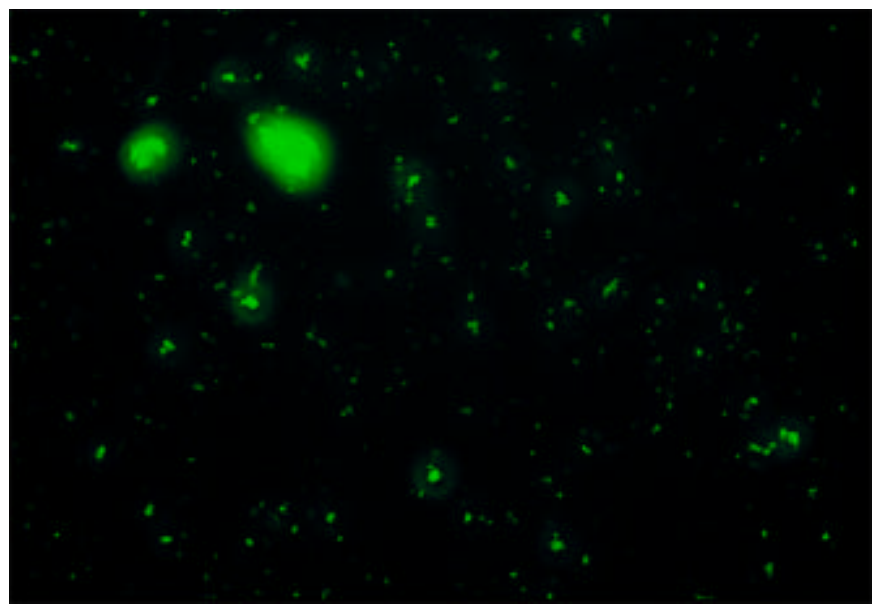

F

Figure 3

Binding of the antibody $\mathrm{Y}_{5}$ E2/Eto BHK cells ( $\left.\mathrm{Y}_{5}\right)$ : A) Normal conditions; B) Blocking of the antibody $\mathrm{Y}_{1} \mathrm{E} 2 / \mathrm{E}$ with a peptide concentration of $10^{-4} \mathrm{M}$

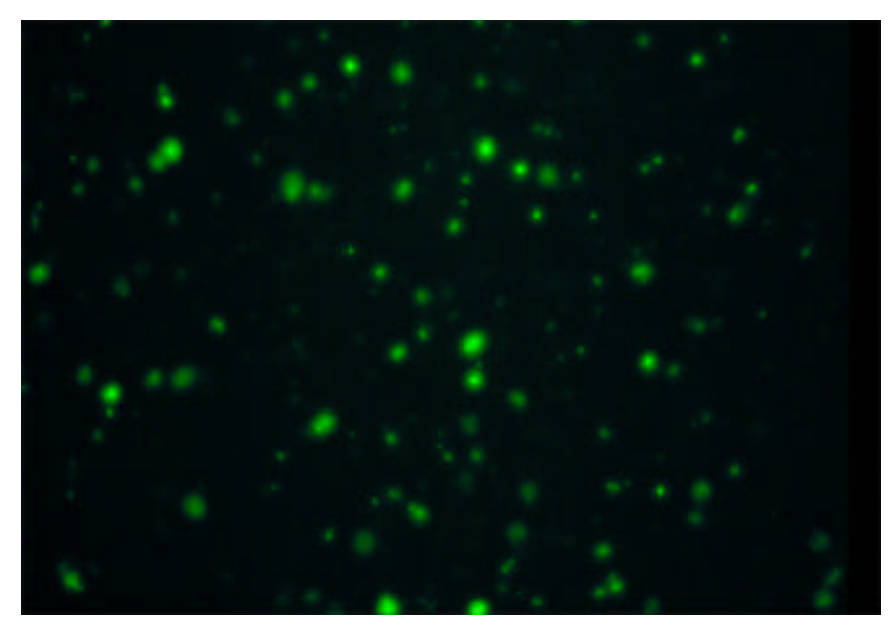

A

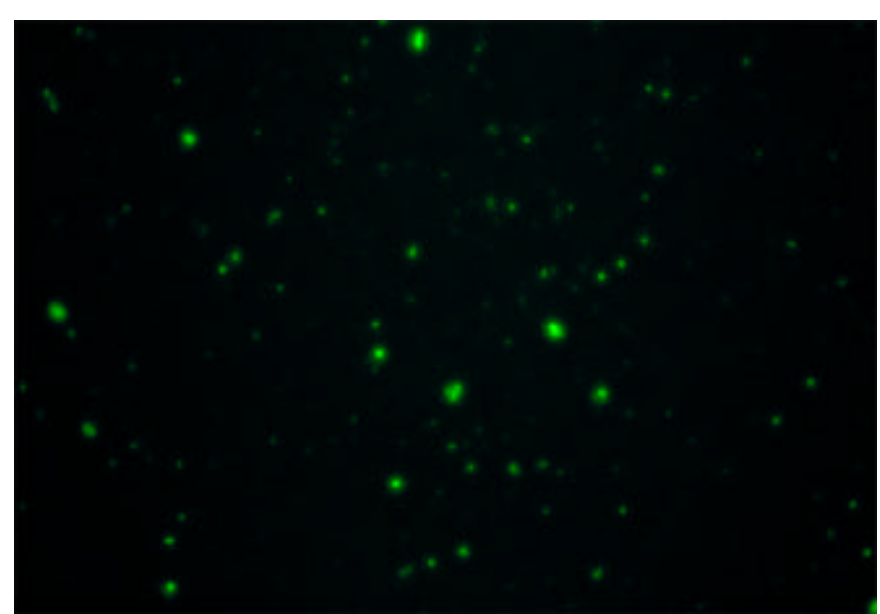

B 
Table 3

Fluorescence microscope detection of Y-receptors on SK-N-MC cells (neuroblastoma, hY $\mathrm{Y}_{1}$ ), SMS-KAN cells (neuroblastoma, $\mathrm{hY}_{2}$ ) and BHK cells (baby hamster kidney cells, $\mathrm{rY}_{5}$ ).

\begin{tabular}{cccc}
\hline antibody & $\begin{array}{c}\mathrm{Y}_{1} \text {-receptor } \\
\text { SK-N-MC }\end{array}$ & $\begin{array}{c}\mathrm{Y}_{2} \text {-receptor } \\
\text { SMS-KAN }\end{array}$ & $\begin{array}{c}\mathrm{Y}_{5} \text {-receptor } \\
\text { BHK }\end{array}$ \\
\hline $\mathrm{Y}_{1} \mathrm{E} 2 / 2$ & + & - & - \\
$\mathrm{Y}_{2} \mathrm{E} 2 / 1$ & - & ++ & - \\
$\mathrm{Y}_{5} \mathrm{E} 2 / 2$ & - & +++ & +++ \\
$\mathrm{Y}_{5} \mathrm{E} 3$ & - & +++ & +++ \\
\hline
\end{tabular}

Key: (-) no fluorescence; (+) weak fluorescence; (++) moderate fluorescence;

$(+++)$ strong fluorescence

\section{Discussion}

The major aim of this work was to compare analogues and anti-receptor antibodies with respect to selectivity and characterisation of the ligand binding site. The NPY/PP system is an unique set that consists of two peptides which bind to five receptors: NPY to $\mathrm{Y}_{1}, \mathrm{Y}_{2}, \mathrm{Y}_{5}$ and $\mathrm{y}_{6}, \mathrm{PP}$ to $\mathrm{Y}_{4}$, but [Pro ${ }^{34}$ NPY to $\mathrm{Y}_{1}, \mathrm{Y}_{4}, \mathrm{Y}_{5}$ and $\mathrm{y}_{6}$. Accordingly, selectivity is a major problem. Furthermore, because of the different effects and the distribution of the receptor, it is of major importance to develop tools that allow the characterisation of the receptors on the protein level. Selective ligands, for example radiolabelled-, fluorescent-labelled- and anti-receptor-antibodies are approaches to address this issue. Furthermore, we were interested in the molecular characterisation of the binding site. Again, ligands with specific replacements [43] and anti-receptor antibodies [44] have been used to map ligand binding. Accordingly, we used both approaches and applied them to the NPY/PP system: on the one hand, full length and centrally truncated NPY analogues were synthesised and their binding potency at the NPY receptor subtypes was tested. On the other hand, polyclonal antibodies raised against synthetic receptor fragments on the second (E2) and third (E3) extracellular loop of the receptor subtypes were tested on intact cells expressing NPY receptors.

The receptor binding properties of the pNPY and hPP analogues presented in this work showed how the affinity of the native ligand at its receptor subtypes can be modulated by modifying its primary structure that is likely to change, consequently, its spatial conformation. It has been supposed that the members of the PP-family adopt a hairpin-like structure which is stabilised by the interdigitation of the tyrosine side chains on the surface of the C-terminal amphipatic $\alpha$-helix with the proline residues of the N-terminus. Accordingly, all NPY receptors have been shown to be sensitive to the positions of Pro 
and Tyr, however each one in a different way. For example, on the base of the Ala-scan results, Pro ${ }^{2}$, $\mathrm{Pro}^{5}$, $\mathrm{Tyr}^{27}$ and $\mathrm{Tyr}^{36}$ proved to be the most important positions for the $\mathrm{hY}_{1}$-receptor, $\mathrm{Pro}^{5}$ and $\mathrm{Tyr}^{36}$ for the $\mathrm{hY}_{2}$-receptor, $\mathrm{Pro}^{8}$ and $\mathrm{Tyr}^{27}$ for the $\mathrm{hY}_{4^{-}}$and $\mathrm{hY}_{5}$-receptor. These differences might be explained by assuming that the proline rich $\mathrm{N}$-terminal region and the $\mathrm{C}$-terminal helix face each other in a way that depends on the structural features of the specific receptor binding site.

The Ala-substitution of the arginine residues also led to different receptor affinities: $\operatorname{Arg}^{19}$ is important for the receptors $h Y_{1}$ and $h Y_{2}$, but not for the receptors $h Y_{4}$ and $h Y_{5}$, whereas $\operatorname{Arg}^{25}$ replacement resulted still in nanomolar affinity at the $\mathrm{hY}_{2}$-receptor only. Instead, $\mathrm{Arg}^{33}$ and $\mathrm{Arg}^{35}$ are essential for the binding at all four subtypes, however it should be emphasised that $\mathrm{Arg}^{33}$ side chain is less important than $\mathrm{Tyr}^{27}$ at the $\mathrm{hY}_{5}$-receptor. Furthermore, $\mathrm{Thr}^{32}$ and $\mathrm{Gln}^{34}$ replacements did not significantly reduce the affinity at the $\mathrm{hY}_{5}$-receptor as they did in the case of the other subtypes. It has been well documented that the C-terminal pentapeptide of NPY represents the receptor binding site for the receptors $Y_{1}$ and $Y_{2}$ [29]. The results presented in this work have shown that this is also the case for the receptors $\mathrm{Y}_{4}$ and $\mathrm{Y}_{5}$, however with different properties. While the Ala-substitution at the positions 32-36 led to a dramatic loss of affinity at the receptors $h \mathrm{Y}_{1}$ and $\mathrm{hY} \mathrm{Y}_{2}$ compared to NPY, in the case of $\mathrm{hY}_{5}$-receptor only the exchange of $\mathrm{Arg}^{35}$ led to a significant decrease in the binding potency. At the $\mathrm{hY}_{4}$-receptor, both arginine residues were found to be crucial for high affinity. This observation suggests that the Y-receptor-ligand interaction is unique for each subtype and it involves different side chains which are required to adopt different spatial orientations, as shown, for example, by the low affinity of the analogue [D-Pro ${ }^{34}$ ]-pNPY at all receptor subtypes. Obviously, D-Pro at the position 34 changes the orientation in an unfavourable way. Accordingly, the amino acid substitution of natural ligands is extremely useful to characterise the ligand binding sites. For NPY it is clear, that it binds to the receptors $\mathrm{Y}_{1}, \mathrm{Y}_{2}$ and $\mathrm{Y}_{5}$ in a very different way with different contact sites (Figure 4). To gain more insight into the mechanism of interaction between the ligand and each receptor, selective compounds are required. Among the Ala-substituted full length NPY analogues, $\left[\mathrm{Ala}^{8}\right]-\mathrm{pNPY},\left[\mathrm{Ala}^{13}\right]-\mathrm{pNPY}$ and $\left[\mathrm{Ala}^{27}\right]$-pNPY can be considered $\mathrm{hY}_{2}$-receptor selective ligands; in particular, the $\mathrm{hY}_{2}$-receptor affinity of $\left[\mathrm{Ala}^{27}\right]$-pNPY is $>100$-fold higher than that at the other receptors.
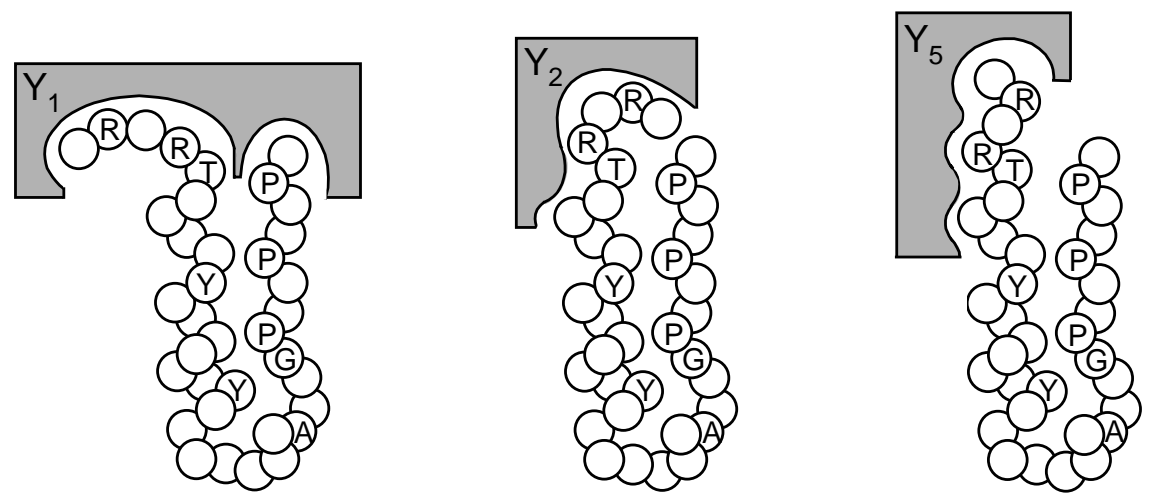

Figure 4: Scheme of different contact sites of NPY at its receptor subtypes. 
Among the centrally truncated NPY analogues, only [Ahx $\left.{ }^{5-24}\right]$-pNPY has been shown to bind selectively to the $\mathrm{hY}_{2}$-receptor. The other longer analogues are characterised by similar affinity values at various subtypes. Interestingly, in some cases comparable affinity could be obtained either by replacement of one position or by removal of a central segment that contains that position. For example, the analogues $\left[\mathrm{Ala}^{13}\right]$-pNPY and $\left[\mathrm{Ahx}^{8-19}\right]$-pNPY bind to the $\mathrm{hY}_{5}$-receptor with an affinity of $17 \mathrm{nM}$ and $19 \mathrm{nM}$, respectively.

To investigate the receptor binding site, also anti-receptor antibodies are useful tools. If the antibodies are obtained against receptor fragments, then the localisation of the functional groups will be possible by competition studies with the ligand. For the $\mathrm{Y}_{1}$-receptor this method has been described by Wieland et al. [44]. In the present work, only a few sera for every receptor subtype were generated. To map the binding site with competition experiments, more sera for every receptor subtype are necessary.

To obtain antibodies which can be used to characterise intact cells, we prepared peptides based on the extracellular loops of the receptors for immunisation. The extracellular loops of the NPY receptors show some similarity, which makes it difficult to achieve full subtype selectivity, which furthermore is difficult to predict. Nevertheless, the generated sera have been shown to be precious tools. For the sera $Y_{1} E 2 / 2$ and $Y_{5} E 2 / 2$, subtype selectivity for the $Y_{1}$ - and $Y_{5}$-receptor subtypes was achieved. The sera $\mathrm{Y}_{5} \mathrm{E} 2 / 2$ and $\mathrm{Y}_{5} \mathrm{E} 3$ bound equally well to the $\mathrm{Y}_{5^{-}}$and the $\mathrm{Y}_{2}$-receptor subtypes. In combination, these sera are able to distinguish between the receptors $Y_{1}, Y_{2}$ and $Y_{5}$. Detection of binding is easy and reliable with a second fluorescent-labelled antibody that is directed against the immunglobulin of the first species. Antibodies also allow receptor localisation investigations in tissue, which is important for the understanding of the physiological effect and of the biological role of a receptor subtype. Moreover, antibodies raised against receptor fragments can be used for many other applications, like molecular mass determination of the receptor protein, affinity purification, receptor regulation, desensitisation and localisation of functional groups [45].

For both NPY analogues and anti NPY receptor antibodies, a rational approach to achieve subtype selectivity is difficult. Ligand-receptor interaction is usually not fully understood for every receptor subtype, which makes prediction of selectivity very hard. Because of sequence similarity amongst receptor subtypes, it is not easy to choose receptor fragments for immunisation that will not lead to any cross-reactivity. Furthermore, the peptides for immunisation may not be too small, in order to obtain the same secondary structure of the segment as in the receptor.

Production of NPY analogues in comparison to antibodies is fast and cheap, but fluorescent labelling of the analogues can influence their binding to the receptor, whereas anti-receptor antibodies can be detected with a secondary, labelled antibody. Furthermore, binding of small peptides on cells or tissue can be difficult to test, because they can be washed out during experimental procedure. 


\section{Conclusions}

The goal of this work was the comparison of selective NPY analogues and anti-receptor antibodies with respect to subtype selectivity and mapping of the binding. For both methods this was partly achieved. The analogues and the antibodies are very good tools to distinguish NPY receptor subtypes on membranes and intact cells. The design and synthesis of new ligands is usually a successful approach to characterise different receptor subtypes conformationally and biologically. In fact, by means of selective analogues it is possible to better understand how each receptor interacts with the ligand and also through which subtype the hormone modulates some physiological functions. Furthermore, these insights are essential for the modelling and the development of new potent drugs, based on a rational design.

In a next step, the analogues and the antibodies have to be tested on tissue because knowledge of receptor distribution is important for the understanding of the physiological and biological role of a receptor subtype. Furthermore, localisation studies should be performed also on the protein level, since mRNA localisation does not fit necessarily with the localisation of the mature protein, as suggested by the observation of the rapid axonal transport for the $\mathrm{Y}_{1}$-receptor [46].

\section{Acknowledgements}

We kindly acknowledge the support of Swiss National Foundation for grant No. 31-05081.97 and the Federal Institute of Technology (ETH) of Zurich for TH project No. 020 218-96.

\section{Experimental}

Synthesis and Characterisation of the NPY Analogues and Segments of Y-Receptors

The NPY analogues and the peptides for immunisation were synthesised by automated multiple solid phase peptide synthesis using a robot system (Syro, MultiSynTech, Bochum, Germany). In order to obtain the C-terminally amidated peptides, the chain assembly was performed on a $0.015 \mathrm{mmol}$ scale using 4-(2',4'-dimethoxyphenyl-Fmoc-aminomethyl)-phenoxy resin (Novabiochem, Läufelfingen, Switzerland) and Fmoc/tert-butyl chemistry. The side chain protection of the Fmocamino acids (Alexis, Läufelfingen, Switzerland) was chosen as follows: Trt for Asn, Gln and His, tertbutyl for Asp, Glu, Ser, Thr and Tyr, Boc for Lys and Trp, and 2,2,5,7,8-pentamethylchroman-6sulfonyl for Arg. A double coupling procedure was performed with diisopropylcarbodiimide/1hydroxy-benzotriazole (Fluka, Buchs, Switzerland) activation, 7-fold excess and a coupling time of 40 min. Fmoc removal was accomplished by $30 \%$ piperidine (Fluka) in DMF for 15 min. The peptide amides were simultaneously cleaved from the resin and deprotected with TFA/thioanisole/thiocresol (Fluka) for 2.5 hours, and collected by precipitation from diethyl ether.

The peptides were purified by preparative HPLC and characterised by analytical HPLC on nucleolsil C-18 column, 5 m, 3 x 125 mm (Merck-Hitachi, Darmstadt, Germany). The elution system 
was $0.1 \%$ TFA in acetonitrile (Scharlau, Barcelona, Spain) (A) and 0.1\% TFA in water (B); a gradient of $15-60 \%$ A or $25-75 \%$ A over 30 min was used. Correct mass was identified by electrospray ionization mass spectrometry (SSQ710, Finnigan, San Jose, CA). The sequence and the chemical characterisation of the peptides are summarised in Tables 1 and 2.

\section{Preparation of the Conjugates and Immunisation}

For the immunisation the peptides were coupled to keyhole limpet hemocyanin (KLH) (Biotrend, Cologne, Germany). Polyclonal antibodies against the KLH-coupled receptor fragments were obtained by immunisation of rabbits (Biotrend, Cologne, Germany).

\section{Titer Determination of the Receptor Segment Peptides}

In order to determine the titer of the antibodies raised against the peptide-KLH conjugates, the peptides were covalently coupled to preactivated ELISA plates (Life Technologies, Basel, Switzerland). The antibody solutions were diluted and incubated at $37^{\circ} \mathrm{C}$ for $90 \mathrm{~min}$. The plates were washed 4 times and the secondary antibody was incubated for 1 hour. After washing the plates 4 times, staining was carried out with 2,2'-azino-bis(3-ethylbenzthiazoline-6-sulfonic acid) (ABTS) and the absorption was subsequently measured at $405 \mathrm{~nm}$ in an ELISA-reader.

\section{Cell Culture}

SK-N-MC cells (neuroblastoma, hY $_{1}$ ) were cultivated in MEM earl's salt (Life Technologies, Basel, Switzerland) supplemented with $10 \%$ (v/v) fetal calf serum (AMIMED, Allschwil, Switzerland), $4 \mathrm{mM}$ L-glutamine, $1 \%$ (v/v) non-essential amino acids (Life Technologies) and $1 \mathrm{mM}$ sodium pyruvate (Life Technologies). SMS-KAN cells (neuroblastoma, $\mathrm{hY}_{2}$ ) were cultivated in Nut-mix HAM's F-12/DMEM 1:1 (Life Technologies) supplemented with 15\% fetal calf serum, 1\% (v/v) Lglutamine and $1 \%(\mathrm{v} / \mathrm{v})$ non-essential amino acids. BHK cells (baby hamster kidney cells, transfected with $\mathrm{hY}_{4}, \mathrm{rY}_{5}$ and $\mathrm{hY}_{5}$ ) were cultivated in DMEM (Life Technologies) supplemented with 10\% (v/v) fetal calf serum, $1 \%$ (v/v) antibiotic-fungicide solution (penicilin $10000 \mathrm{U} / \mathrm{ml}$, streptomycin $10 \mathrm{mg} / \mathrm{ml}$ and fungizone $25 \mu \mathrm{g} / \mathrm{ml}$; AMIMED) and $1 \mathrm{mg} / \mathrm{ml}$ geneticin (G418; SIGMA, Buchs, Switzerland). Additionally, $1 \mathrm{mg} / \mathrm{ml}$ Hygromicin and 24 hours before harvest $1 \mathrm{mM}$ IPTG was added to the $\mathrm{rY}_{4}$ expressing BHK cells. Cells were maintained at $37{ }^{\circ} \mathrm{C}$ in a humidified atmosphere containing $5 \% \mathrm{CO}_{2}$ and $95 \%$ air in $75 \mathrm{~cm}^{2}$ flasks (Techno Plastic-Products AG, Trasadingen, Switzerland). They were harvested at $100 \%$ confluency in phosphate buffered saline (PBS; Life Technologies) containing 0.02\% EDTA. 


\section{Binding Potency of NPY Analogues}

Membrane suspensions obtained from SK-N-MC (hY 1$)$, SMS-KAN $\left(\mathrm{hY}_{2}\right)$ and BHK $\left(\mathrm{r} / \mathrm{hY}_{4}, \mathrm{r} / \mathrm{hY}_{5}\right)$ cells $(100 \mu \mathrm{l})$ were prepared as described previously [28, 30], and incubated with $30 \mathrm{pM}{ }^{125}$ I-BoltonHunter-NPY $\left({ }^{125}\right.$-BH-NPY) or $1.2 \mathrm{nM}\left[{ }^{3} \mathrm{H}\right]$-propionyl-NPY $\left(\left[{ }^{3} \mathrm{H}\right]-\mathrm{NPY}\right.$ and different concentrations of the peptide in a total volume of $250 \mu \mathrm{l}$ for 2 hours at room temperature as described recently [28, 39, 40]. The protein-bound radioactivity was determined in a $\gamma$-counter. The nonspecific binding is defined as radioactivity bound in the presence of $1 \mu \mathrm{M}$ NPY during the incubation period. Half-maximal inhibition of the specific binding of ${ }^{125}$-BH-NPY or $\left[{ }^{3} \mathrm{H}\right]-\mathrm{NPY}$ of two to three separate experiments each performed in triplicate is given as the $\mathrm{IC}_{50}$ value.

\section{Immunofluorescence}

Affinity of the anti-receptor antibodies was investigated at $\mathrm{Y}_{1}$-receptor expressing SK-N-MC cells (neuroblastoma, $\mathrm{hY}_{1}$ ), SMS-KAN cells (neuroblastoma, $\mathrm{hY}_{2}$ ) and transfected BHK cells (baby hamster kidney cells, $\mathrm{rY}_{5}$ ). About 500000 cells per well were added to 12 well tissue culture test plates (Techno Plastic-Products) and grown to confluency. Antisera were diluted 1:50 in the corresponding cell culture media, $1.5 \mathrm{~mL}$ antisera solution was added per well. Tissue culture test plates were incubated for 90 min at $37{ }^{\circ} \mathrm{C}$ and washed twice with media. Goat anti-rabbit 4(5)-fluoresceinisothiocyanate (FITC) conjucated IgG (SIGMA, Buchs, Switzerland) was diluted 1:80 in media, $1 \mathrm{~mL}$ antisera solution was added per well. Tissue culture test plates were incubated for 1 hour at $37{ }^{\circ} \mathrm{C}$ and washed twice with media. The cells were viewed in a fluorescence microscope (Zeiss, D-Oberkochen; Axiovert 35, Filters: excitation: BP 450-490 nm, beamsplitter FT 510, emission LP 520). As positive control, one lane of each plate was directly incubated with goat anti-rabbit FITC coupled IgG. For the negative control, anti-receptor antisera were preincubated for 1 hour with the corresponding antigen peptide in concentrations of $10^{-5} \mathrm{M}$ or $10^{-4} \mathrm{M}$. Incubation of the antibody solutions as well as detection was performed as described above.

\section{References}

1. Tatemoto, K.; Carlquist, M.; Mutt, V. Neuropeptide Y--a novel brain peptide with structural similarities to peptide YY and pancreatic polypeptide. Nature, 1982, 296, 659-660.

2. Inui, A. Neuropeptide Y feeding receptors: are multiple subtypes involved? Trends Pharm. Sci., 1999, 20, 43-46.

3. Kalra, S. P.; Crowley, W. R. Neuropeptide Y: a novel neuroendocrine peptide in the control of pituitary hormone secretion, and its relation to luteinizing hormone. Front. Neuroendocrinol., 1992, $13,1-46$. 
4. McDonald, J. K.; Lumpkin, M. D.; Samson, W. K.; McCann, S. M. Neuropeptide Y affects secretion of luteinizing hormone and growth hormone in ovariectomized rats. Proc. Natl. Acad. Sci. U.S.A., 1985, 82, 561-564.

5. Moltz, J. H.; McDonald, J. K. Neuropeptide Y: direct and indirect action on insulin secretion in the rat. Peptides, 1985, 6, 1155-1159.

6. Wahlestedt, C.; Yanaihara, N.; Håkanson, R. Evidence for different pre- and postjunctional receptors for neuropeptide Y and related peptides. Regul. Pept., 1986, 13, 307-318.

7. Flood, J. F.; Hernandez, E. N.; Morley, J. E. Modulation of memory processing by neuropeptide Y. Brain Res., 1987, 421, 280-290.

8. Jolicoeur, F. B.; Michaud, J. N.; Rivest, R., Menard, D.; Gaudin, D.; Fournier, A.; St-Pierre, S. Neurobehavioral profile of neuropeptide Y. Brain. Res. Bull., 1991, 26, 265-268.

9. Jolicoeur, F. B.; Michaud, J. N.; Menard, D.; Fournier, A. In vivo structure activity study supports the existence of heterogeneous neuropeptide Y receptors. Brain. Res. Bull., 1991, 26, 309-311.

10. Esteban, J.; Chover, A. J.; Sanchez, P. A.; Mico, J. A.; Gibert-Rahola, J. Central administration of neuropeptide $\mathrm{Y}$ induces hypothermia in mice. Possible interaction with central noradrenergic systems. Life Sci., 1989, 45, 2395-2400.

11. Clark, J. T.; Kalra, P. S.; Kalra, S. P. Neuropeptide Y stimulates feeding but inhibits sexual behavior in rats. Obes. Res., 1997, 5, 275-283.

12. Calza, L.; Giardino, L.; Zanni, M.; Velardo, A.; Parchi, P.; Marrama, P. Daily changes of neuropeptide Y-like immunoreactivity in the suprachiasmatic nucleus of the rat. Regul. Pept., 1990, 27, 127-137.

13. McAuley, M. A.; Chen, X.; Westfall, T. C. Central cardiovascular actions of neuropeptide Y. In: The biology of neuropeptide $Y$ and related peptides; Colmers, W. F., Wahlestedt, C. (ed.), Humana Press Inc., Totowa. 1993; pp. 389-418.

14. Heilig, M. Neuropeptide $\mathrm{Y}$ in relation to behavior and psychiatric disorders: some animal and clinical observations. In: The biology of neuropeptide $Y$ and related peptides; Colmers, W. F., Wahlestedt, C. (ed.), Humana Press Inc., Totowa. 1993; pp. 511-555.

15. Thiele, T. E.; Marsh, D. J.; Marie, L. S., Bernstein, I. L.; Palmiter, R. D. Ethanol consumption and resistance are inversely related to neuropeptide Y levels. Nature, 1998, 396, 366-369.

16. Michel, M. C.; Beck-Sickinger, A. G.; Cox, H.; Doods, H. N.; Herzog, H.; Larhammar, D.; Quirion, R.; Schwartz, T.; Westfall, T. XVI. International union of pharmacology 
recommendations for the nomenclature of neuropeptide $\mathrm{Y}$, peptide $\mathrm{YY}$, and pancreatic polypeptide receptors. Pharmacol. Rev., 1998, 50, 143-150.

17. Krause, J.; Eva, C.; Seeburg; P. H.; Sprengel, R. Neuropeptide Y1 subtype pharmacology of a recombinantly expressed neuropeptide receptor. Mol. Pharmacol., 1992, 41, 817-821.

18. Larhammar, D.; Blomqvist, A. G.; Yee, F.; Jazin, E.; Yoo, H.; Wahlestedt, C. Cloning and functional expression of a human neuropeptide Y/peptide YY receptor of the Y1 type. J. Biol. Chem., 1992, 267, 10935-10938.

19. Herzog, H.; Hort, Y. J.; Ball, H. J.; Hayes, G.; Shine, J.; Selbie, L. A. Cloned human neuropeptide Y receptor couples to two different second messenger systems. Proc. Natl. Acad. Sci. U.S.A., 1992, 89, 5794-5798.

20. Rose, P. M.; Fernandes, P.; Lynch, J. S.; Frazier, S. T.; Fisher, S. M.; Kodukula, K.; Kienzle, B.; Seethala, R. Cloning and functional expression of a cDNA encoding a human type 2 neuropeptide Y receptor. J. Biol. Chem., 1995, 270, 29038.

21. Gerald, C.; Walker, M. W.; Vaysse, P. J.; He, C.; Branchek, T. A.; Weinshank, R. L. Expression cloning and pharmacological characterization of a human hippocampal neuropeptide Y/peptide YY Y2 receptor subtype. J. Biol. Chem., 1995, 270, 26758-26761.

22. Gehlert, D. R.; Beavers, L. S.; Johnson, D., Gackenheimer; S. L., Schober, D. A.; Gadski, R. A. Expression cloning of a human brain neuropeptide Y Y2 receptor. Mol. Pharmacol., 1996, 49, 224228.

23. Lundell, I.; Blomqvist, A. G.; Berglund, M. M.; Schober, D. A.; Johnson, D.; Statnick, M. A.; Gadski, R. A.; Gehlert, D. R.; Larhammar, D. Cloning of a human receptor of the NPY receptor family with high affinity for pancreatic polypeptide and peptide YY. J. Biol. Chem., 1995, 270, 29123-29128.

24. Bard, J. A.; Walker, M. W.; Branchek, T. A.; Weinshank, R. L. Cloning and functional expression of a human Y4 subtype receptor for pancreatic polypeptide, neuropeptide Y, and peptide YY. $J$. Biol. Chem., 1995, 270, 26762-26765.

25. Gerald, C.; Walker, M. W.; Criscione, L.; Gustafson, E. L.; Batzl-Hartmann, C.; Smith, K. E.; Vaysse, P.; Durkin, M. M.; Laz, T. M.; Linemeyer, D. L.; Schaffhauser, A. O.; Whitebread, S.; Hofbauer, K. G.; Taber, R. I., Branchek; T. A.; Weinshank, R. L. A receptor subtype involved in neuropeptide-Y-induced food intake. Nature, 1996, 382, 168-171.

26. Weinberg, D. H.; Sirinathsinghji, D. J.; Tan, C. P.; Shiao, L. L.; Morin, N.; Rigby, M. R.; Heavens, R. H.; Rapoport, D. R.; Bayne, M. L.; Cascieri, M. A.; Strader, C. D.; Linemeyer, D. L.; MacNeil, D. J. Cloning and expression of a novel neuropeptide Y receptor. J. Biol. Chem., 1996, 271, 1643516438. 
27. Beck-Sickinger, A. G. Structural characterization and binding sites of G-protein coupled receptors. Drug Discov. Today, 1996, 1, 502-513.

28. Ingenhoven, N.; Beck-Sickinger, A. G. Fluorescent labelled analogues of neuropeptide Y for the characterization of cells expressing NPY receptor subtypes. J. Rec. \& Signal Transd. Res., 1997, 17, 407-418.

29. Beck-Sickinger, A. G.; Jung, G. Structure-activity relationships of neuropeptide Y analogues with respect to Y1 and Y2 receptors. Biopolymers, 1995, 37, 123-142.

30. Rist, B.; Wieland, H. A.; Willim, K. D.; Beck-Sickinger, A. G. A rational approach for the development of reduced-size analogues of neuropeptide $\mathrm{Y}$ with high affinity to the Y1 receptor. $J$. Pept. Sci., 1995, 1, 341-348.

31. Jahns, R. ; Siegmund, C. ; Jahns, V. ; Reilander, H. ; Maidhof, A. ; Muller-Esterl, W. ; Lohse, M. J. ; Boege, F. Probing human beta 1- and beta 2-adrenoceptors with domain-specific fusion protein antibodies. Eur. J. Pharm., 1996, 316, 111-121.

32. Wall, S. J. ; Yasuda, R. P.; Hory, F.; Flagg, S.; Martin, B. M.; Ginns, E. I.; Wolfe, B. B. Production of antisera selective for $\mathrm{m} 1$ muscarinic receptors using fusion proteins: distribution of $\mathrm{m} 1$ receptors in rat brain. Mol. Pharmacol., 1991, 39, 643-649.

33. Muller-Newen, G.; Kohne, C.; Keul, R.; Hemmann, U.; Muller-Esterl, W.; Wijdenes, J.; Brakenhoff, J. P.; Hart, M. H.; Heinrich, P. C. Purification and characterization of the soluble interleukin-6 receptor from human plasma and identification of an isoform generated through alternative splicing. Eur. J. Biochem., 1996, 236, 837-842.

34. Abd Alla, S.; Godovac-Zimmermann, J.; Braun, A.; Roscher, A. A.; Muller-Esterl, W. ; Quitterer, U. Structure of the bradykinin B2 receptors' amino terminus. Biochemistry, 1996, 35, 7514-7519.

35. Van den Pol, A. N.; Romano, C.; Ghosh, P. Metabotropic glutamate receptor mGluR5 subcellular distribution and developmental expression in hypothalamus. J. Comp. Neurol., 1995, 362, 134-150.

36. Westphal, R. S.; Backstrom, J. R.; Sanders-Bush, E. Increased basal phosphorylation of the constitutively active serotonin $2 \mathrm{C}$ receptor accompanies agonist-mediated desensitization. Mol. Pharmacol., 1995, 48, 200-205.

37. Palmer, T. M.; Gettys, T. W.; Jacobson, K. A.; Stiles, G. L. Desensitization of the canine A2a adenosine receptor: delineation of multiple processes. Mol. Pharmacol., 1994, 45, 1082-1094.

38. Ingenhoven, N.; Eckard, C. P.; Gehlert, D. R.; Beck-Sickinger, A. G. Molecular characterization of the human neuropeptide Y Y2-receptor. Biochemistry, 1999, 38, 6897-6902. 
39. Rist, B.; Ingenhoven, N.; Scapozza, L.; Schnorrenberg, G.; Gaida, W.; Wieland, H. A.; BeckSickinger, A. G. The bioactive conformation of neuropeptide Y analogues at the human Y2receptor. Eur. J. Biochem., 1997, 247, 1019-1028.

40. Beck-Sickinger, A. G.; Wieland, H. A.; Wittneben, H.; Willim, K. D.; Rudolf, K.; Jung, G. Complete L-alanine scan of neuropeptide Y reveals ligands binding to Y1 and Y2 receptors with distinguished conformations. Eur. J. Biochem., 1994, 225, 947-958.

41. Allen, J.; Novotny, J.; Martin, J.; Heinrich, G. Molecular structure of mammalian neuropeptide Y: analysis by molecular cloning and computer-aided comparison with crystal structure of avian homologue. Proc. Nat. Acad. Sci. U.S. A., 1987, 84, 2532-2536.

42. Beck, A. G.; Jung, G.; Gaida, W.; Köppen, H.; Lang, R.; Schnorrenberg, G. Highly potent and small neuropeptide $\mathrm{Y}$ agonist obtained by linking NPY 1-4 via spacer to a-helical NPY 25-36. FEBS Lett., 1989, 244, 119-122.

43. Rist, B.; Entzeroth, M.; Beck-Sickinger, A. G. From micromolar to nanomolar affinity: a systematic approach to identify the binding site of CGRP at the human calcitonin gene-related peptide 1 receptor. J. Med. Chem., 1998, 41, 117-123.

44. Wieland, H. A.; Eckard, C. P.; Doods, H. N.; Beck-Sickinger, A. G. Probing of the neuropeptide YY-1-receptors interaction with anti-receptor antibodies. Eur. J. Biochem., 1998, 255, 595-603.

45. Eckard, C. P.; Beck-Sickinger, A. G. Anti-receptor antibodies to characterize G-protein coupled receptors, Curr. Med. Chem., 2000, 7, 897-910.

46. Jacques, D.; Tong, Y.; Dumont, Y.; Shen, S. H.; Quirion, R. Expression of the neuropeptide Y Y1 receptor mRNA in the human brain: an in situ hybridization study. Neuroreport, 1996, 7, 1053-1056.

Sample Availability: Contact authors

(C) 2001 by MDPI (http://www.mdpi.org). Reproduction is permitted for noncommercial purposes 